\title{
Cytochrome P450 26A1
}

National Cancer Institute

\section{Source}

National Cancer Institute. Cytochrome P450 26A1. NCI Thesaurus. Code C126985.

Cytochrome P450 26A1 (497 aa, 56 kDa) is encoded by the human CYP26A1 gene. This protein is involved in the hydroxylation of retinoic acid. 